\title{
The Other Stance \\ Conflicting Professional Self-Images \\ and Perceptions of the Other Profession \\ among Finnish PR Professionals and Journalists
}

\author{
Niina Niskala \& Pertti Hurme
}

\begin{abstract}
Public relations (PR) professionals and journalists act as builders of societies' communication atmospheres, and their inter-relationships are of importance. The aim of the present study is to describe and compare PR professionals' and journalists' professional self-images and perceptions of the other group's profession in Finland. The study is part of the ProfCom project and makes use of the project's Finnish quantitative questionnaire data. The results indicate clear perception differences. PR professionals identify themselves with bond- and trust-building objectives, whereas journalists perceive marketing and financial goals as the main objectives of PR professionals. Journalists identify themselves with information sharing, criticism and service roles, whereas PR professionals perceive opinion sharing, advising and informing about scandals as the main objectives of journalists. In addition, the study indicates a need for further research on the underlying reasons for conflicting perceptions and the effects of the developing Internet communication arena on relationships between professionals.
\end{abstract}

Keywords: PR professionals, journalists, professional self-image, role, image, perception.

\section{Introduction}

Public Relation (PR) professionals and journalists have crucial and meaningful roles in society. Together they act as forces that help in the formation of public knowledge, opinion and deliberation, and they are generally seen as vital parts of the democratic process. Their relationship is often thought to be conflicting, as they may be perceived to work at the opposite extremes of organizational communication and public communication.

The differences in the perceptions, roles and objectives of PR professionals and journalists have been extensively studied, and the two groups have been described as having, among other things, antagonist, dependent and love-hate relationships. However, there are, to our knowledge, no equivalent comparative studies on how Finnish journalists and PR professionals view their own and each other's professions and objectives. Professional self-images and perceptions of the other group's professional objectives may have an impact on the relationship and trust-building between the two occupations. The relationship may also have an impact on the communication atmosphere and trust in society at large. 
The objective of the present study is to describe professional self-images and perceptions of the other group among PR and journalist professions in Finland based on quantitative online survey data. The study is part of the ProfCom project - a Europeanwide cross-cultural comparative study of journalists and public relations managers - led by the University of Vienna, Austria (ProfCom 2011) ${ }^{1}$.

\section{Finnish Media and Public Relations Sphere}

The World Democracy Audit (2012) ranks Finland as the first in democracy, press freedom and lack of corruption in comparison to 150 other countries. Karppinen, Nieminen and Markkanen (2011: 113) describe Finland as a small welfare state with a very concentrated autonomous media system and high professional norms and journalistic ethics. The media have had and continue to have an important social function and status in Finland. In the Hallin and Mancini (2004) framework, Finnish journalists belong to the North/Central European or Democratic Corporatist Model. Compared to the formalization of the Finnish press more than one hundred years earlier, PR has a short history in Finland, professionally formalizing only after World War II (e.g., von Hertzen, Melgin \& Åberg 2012).

As Trappel, Nieminen and Nord (2011: 7) state, "Mass media are the essential elements of all forms of democratic societies." This entails upholding the core fields of freedom, equality and control in societies. In other words, the media should mediate between groups and interests in times of conflict, and control the possible abuses of institutions and power holders. The media have also been named the Fourth Estate - an independent democratic institution, alongside society's legislative power (parliament), executive power (government) and judicial power (court) (e.g., Nieminen \& Nordenstreng 2012: 320 and Dutton 2009: 2). Organizations operate in the same public arena as the media, but with different objectives, such as forming a positive image of the organization. Reputation management can have an effect on both the public's purchase and investment decisions as well as on media attitudes towards companies (Fombrun \& van Riel 2004: 2-4). Organizational communicators can be important societal actors, balancing information flows, transparency and relationships between an organization and its stakeholder, i.e. all parties and groups that can affect, or be affected by, the organization (Lehtonen 2002: 14-15). Because the media's agenda-setting function also has the power to position organizations differently from the viewer perspective (Fombrun \& van Riel 2004: 14), journalists and the news they produce affect the images of and trust people have in organizations.

According to the largest and most recent Finnish communication professional survey with 1378 respondents (Viestinnän ammattilaiset -tutkimus 2011), the main tasks of PR professionals include internal communication (41\%), digital (Internet) communication $(38 \%)$, media relations and surveillance (37\%), magazines and publications $(31 \%)$, communication management (23\%), and reputation and brand management $(21 \%)$. Their most common professional titles include communication/PR manager (23\%), publicist/ PR officer (22\%), and specialist/consultant (11\%). The gender ratios (Women\%/Men\%) for the respondents' professional titles reveal the predominance of women: communication assistants 95:05, communication managers 90:10, communication specialists 89:11, and communication executives 75:25. 
Statistics show that in 2011 personnel in mass media enterprises in Finland worked with the following types of activities: publishing $65 \%$, programming and broadcasting $19 \%$, motion picture, video and television programme production $11 \%$, sound recording and music publishing $2 \%$, web portals $2 \%$, and news agencies $1 \%$ (Official Statistics of Finland 2011a). At the end-user level, the mass media market volume in Finland in 2011 consisted of three sectors: printed media $64 \%$, electronic media $30 \%$, and recorded media 6\% (Official Statistics of Finland 2011b). According to Jyrkiäinen (2012: 84), there were 16,000 journalists who were members of The Union of Journalists in Finland in 2011 , of whom $57 \%$ were women.

\section{Professional Self-images and Other's Perceptions}

When defining individual self-perception, several conceptualizations have been used such as the ideal self, the apparent self, the social self, the perceived self, and the actual self (see Heath \& Scott 1998: 1111). Many researchers, nevertheless, hold to the more general definitions of self-image (Rogers, Kuiper \& Kirker 1977) and self-concept (e.g., Graeff 1996). Graeff (1996: 5) defines self-concept as "an individual's perception of one's own abilities, limitations, appearance and characteristics, including one's own personality". Ohman $(1992,1-4)$ explains that self-images are built on the way people experience significant messages from others and the way people perceive others' actions towards them. Both early and late experiences influence the development of self-images, which change throughout life.

When the self is viewed in the work context, terms such as professional identity (e.g., Kirpal 2004 and Robson 1998) and professional self-image are used. In the present study, the latter concept is adopted. Professional self-image indicates personal identity and working roles in specific contexts and is seen to influence professional attitudes, values, positions, and actions (Collard 2004: 37). Professional self-image can also be viewed as the sum of subjective and inter-subjective attitudes affected by past professional experience and context (Volek \& Jirák 2007: 362). Many studies have underscored the significance of professional self-image for work processes and professional objectives in various fields, such as education and management (Collard 2004), nursing (Siebens et al. 2006), real estate (Webb 2000), and journalism (Volek \& Jirák 2007).

The concepts 'image' and 'perception' are used interchangeably in the present study. Image can be defined as "the set of beliefs, ideas, and impressions that a person holds regarding an object" (Kotler 1997: 273). Both images and perceptions are, thus, regarded as the sum of opinions and beliefs held by one or many people and formed based on how things appear to people.

Images and perceptions are significant because they can lead to feelings and attitudes, for example of trust, and consequently have behavioural outcomes. Thus, attitudes can be thought to be closely related to image formation. Attitude strength has been shown to have an impact on how passionately people react to incidents. Especially self-interest, social identification and values can have an impact on the magnitude of attitudes (Berent, Boninger \& Krosnick 1995: 61-64). 


\section{Professional Roles, Objectives and Relationships of Journalists and PR Professionals}

Roles can be seen as "abstractions of behaviour patterns of individuals in organizations" (Dozier 1992: 327). Roles help in understanding the functions of practitioners and can have an impact on professional achievements, structures and processes (ibid.).

Many studies have aimed at conceptualizing the professional roles and self-images of journalists. Traditional typologies include characterizations of journalists as neutrals and participants (Johnston, Slawski \& Bowman 1976: 122-123). The neutrals are described as the nothing-but-the-truth journalists with highly objective non-personal approaches, presenting only news that can be thoroughly verified. The participants are characterized as whole-truth journalists who gather all relevant information concerning a news item, process it thoroughly, and present the relevant information to the public. Culbertson (1983: 1-3), on the other hand, introduces three types of self-images or roles of journalists. First, interpretative roles which involve a good deal of information processing before making decisions and reporting facts. This role is related to the neutrals. Second, traditional roles involve endorsement of traditional conventions of news production, such as timeliness, human interest and formal layout. This role is related to the participant role. Finally, activist roles involve a concern with constraints that can limit the treatment of controversies.

Wilhoit and Weaver (1996) argue for a three-role typology of disseminator, interpreter and adversary. Macnamara (2007: 6) states that journalism originally evolved with a strong practical focus and that journalists still do not want to influence audiences but instead are drawn to the "information model - the "provide the facts, let the public decide' school of journalism thinking", thus emphasizing the disseminator self-image and role of journalists. Then again, Volek and Jirák (2007) suggest that along with the three traditional journalistic objectives of education, advocate/adversarial, and neutral/ objective, a fourth career/pragmatic objective can be discerned. This new objective emphasizes personal work advancement and self-emphasis/disclosure instead of idealistic goals of social change and is seen as a result of the increased competition and marketing aspects of modern media.

Several public relations roles have been identified in previous studies. Broom and Smith (1979) conceptualize four public relations roles: the expert prescriber, the communication facilitator, the problem-solving process facilitator, and the communication technician. Dozier (1992) introduces a new categorization with two dominant roles, the manager (relating to Broom and Smith's first three roles) and the technician, and two minor roles, the media relations specialist and the communication liaison.

After an extensive public relations literature review and a Dutch survey, van Ruler (2004) identifies seven PR typologies: (1) town crier (public relations is broadcasting his master's voice), (2) steward (public relations is pampering), (3) traffic manager (public relations is transfer), (4) conductor (public relations is harmonic performance), (5) creator (public relations is about creating a bond) and (6) facilitator (public relations is hosting a dialogue). The final role is not visible in the literature but emerges from various texts, such as interviews, columns and biographies. This seat-of-the-pants view implies that PR is simply something people either can or cannot do (public relations is an art, not a profession). Notably, van Ruler concludes that only four of these can be 
taken seriously as public relations strategies: information (traffic manager), persuasion (conductor), consensus-building (creator), and dialogue (facilitator).

There are many studies concerning the relationships of PR professionals and journalists. Ryan and Martinson (1988), for instance, acknowledge the love-hate relationships between PR professionals and journalists, where 'love' refers to journalists using PR for sources and material, and 'hate' refers to journalists viewing PR professionals as unreliable sources. Charron (1989) describes the relationship in terms of cooperation and conflict.

According to Larsson's (2009) interviews with Swedish communication professionals, the relationship is mutually dependent; PR professionals aim at planting ideas in the media and when resources are decreased, journalists tend to depend on PR material. PR professionals' objective is to build long-term relations with journalists and respect journalists' public dissemination role, whereas journalists often deny close relations with PR professionals, i.e. acceptance of news ideas from them, and have quite sceptical attitudes towards PR professionals. Salter (2005) takes a more radical stand, arguing that to preserve good, ethical journalism and democratic practices, journalists and the media should be protected from time constraints, ready-made PR material and PR professionals' objectives to take advantage of journalists for their private gain. In this view, PR and organizations benefit from journalism, but journalism does not benefit from PR.

Ryan and Martinson (1988) find that PR professionals regard journalists' antagonism towards PR as stemming from: 1) negative experiences with unprofessional practitioners, 2) journalists' perceptions of their own work as more important, 3) journalists' exaggerated view of their status, 4) general journalist biases, and 5) feelings of being used. According to PR professionals, journalists' perceptions are generally not justifiable, and could be corrected by mutual understanding and education (ibid.). Shin and Cameron's (2004) study of 641 American PR professionals' and journalists' perceptions of each other also confirmed the conflicting perceptions between the groups. In their view, for instance, maintaining conventional professional roles (PR as source, journalists as mere reporters) act as strategic choices that can increase the conflict.

Bowen (2009) also raises many PR profession-related issues that have an effect on the relationship between the professionals: The PR profession appears vague to people outside the industry, its stature lags behind other professions and a perceived lack of general (ethical) standards affects its credibility. It can be argued that PR generally has a bad image, lacks professional status, and that some PR would be needed to make its roles and functions, and service to society and democracy, visible to everyone (e.g., Bowen 2009, Meintjes \& Niemann-Struweg 2009 and Simmons \& Walsh 2010). Van Ruler (2004: 123) similarly notes that negative images and "questionable behaviour in PR" are related to the lack of professional categorization and criteria in the field of public relations.

In conclusion, as PR professionals and journalists operate within the same public arena, they influence and learn from each other (Schriner 2008: 4). Researchers, such as Jempson (2005), acknowledge many professional objective issues between PR professionals and journalists that have an impact on their relationship and trust. PR professionals are often seen as presenting only positive aspects of their organization, and journalists can be subject to scepticism concerning their research skills and source accuracy. Therefore, the relationship between these professions raises weighty questions: Can journalists trust the information coming from PR professionals? Can PR profes- 
sionals trust journalists to report their statements accurately? Lastly, can the public trust the information received from either communication profession?

\section{Methods}

\section{Research Questions}

Being descriptive in nature, the present study is guided by three research questions:

1. How do PR professionals and journalists perceive their own profession and objectives?

2. What kind of perceptions do PR professionals and journalists have of each other's profession and objectives?

3. What kinds of differences are there between professional self-images and the other group's perceptions?

\section{Data and Analysis}

The research premises of this study lie within the Professional Communicators in Europe (ProfCom) project, which started in 2009 at the University of Vienna, Austria. The project objective is a European-wide cross-cultural comparison of self-concepts of journalists and PR managers and their perception of the other group. The project focuses on both similarities and differences in the professional self-conception of both groups, on professional ethics and personal values.

An online Internet survey was conducted to gather data from journalists and PR professionals from various European countries. The University of Vienna, as the project coordinator, was in charge of questionnaire development, pretesting and data management. Each country was responsible for sample recruiting and translating the questionnaire to their respective languages. The survey was constructed to analyse self-image and perception by the other profession within one and the same survey.

The Finnish data were gathered through an Internet survey in spring 2010. A letter concerning participation in the survey was sent to the largest Finnish media and communication professional associations, which shared the message and survey link with their members via webpages, letters and social media. The associations included The Union of Journalists in Finland, The Finnish Association of Communications Professionals (ProCom) and an association of communication specialists (Viesti ry). Altogether 157 PR professionals and 143 journalists completed the questionnaire. Although the exact response rate is unknown due to the sampling method (snowball sampling), the target population is well presented as the members of the associations represent generalizable groups of Finnish journalists and PR professionals.

The questionnaires were targeted at each professional group but were largely identical. The questionnaires comprised demographic and professional background items, professional self-image and the other group's image items, professional ethic and value items, and EU-related image items. Question batteries consisted of Likert-type scale evaluative items. The scales used will be described in the results.

As the present study focuses on the image perspective, the professional self-image and image section of the questionnaire is given prominence in the analysis. The analysis 
is mainly based on four identical question batteries from both questionnaires. Three of them focused on PR perceptions and one extensive battery on journalist perceptions, each comprising several statements. Some of the image question statements were rated by the present authors as neutral or negative (not in the original questionnaire) to give a quick overview of the perception difference. The results were analysed using SPSS 18. The analytical focus was on statistical averages within the groups and significant differences (ANOVA, F-test) between the groups.

Among the respondents completing this survey, the gender distribution clearly differed between journalists and PR professionals: $12 \%$ of PR professionals were men, $88 \%$ women. On the other hand, $49 \%$ of journalists were men, $51 \%$ women. The age distribution was rather similar both for those under 35 and above 56 years, and the average age was 44 years in both groups. However, there were more PR professionals in the age cohort $36-45$ than journalists $(28 \%$ vs. $20 \%)$ and more journalists in the age cohort 46-55 than PR professionals (33\% vs. 27\%). PR professionals had a better education than journalists; $85 \%$ of them had a university or polytechnic degree (vs. 64\%). Journalists more often had unfinished university studies ( $23 \%$ vs. $6 \%$ ) or no studies after high school (7\% vs. $1 \%)$.

PR professionals have less work experience than journalists (13 years vs. 20 years on average). Most journalists work as journalists (74\%), 90\% of them working for printed newspapers and $22 \%$ with online versions of printed newspapers (only small percentages working for other special papers, weekly/monthly papers, radio or TV), and $23 \%$ of them are in leading positions ( $3 \%$ in other positions). Among PR professionals the 'other positions' group is large (37\%); 29\% work as PR officers, and 34\% as PR managers. Most PR professionals work in the governmental/public sector (54\%), 15\% in corporations, $13 \%$ in NGOs, $2 \%$ in PR firms, $2 \%$ as entrepreneurs, and $14 \%$ in other organizations.

Forty-three percent of PR professionals work or have previously worked in journalism alongside PR work, but only $6 \%$ of them used to work solely in journalism before switching to PR work. Only $15 \%$ of journalists work or have worked in PR alongside their profession, and even fewer (8\%) used to work solely in PR before their journalist careers. On the other hand, $48 \%$ of PR professionals and $47 \%$ of journalists can imagine working in the other profession in the future.

\section{Results}

\section{PR Professionals' Functions and Objectives - Self-images and Journalists' Perceptions}

Three question batteries in the PR questionnaire examined PR professionals' functions and objectives. Correspondingly, three questions in the journalist questionnaire examined journalists' perceptions of PR professionals' functions and objectives.

The first function question for PR professionals was: When you consider yourself as a PR professional, which of the following statements describe your behaviour well, and which poorly? The first question posed to journalists was: Which of the following statements describe PR professionals well, and which poorly? The respondents were asked to arrange the statements from the most important (1) to the least important (5). Table 1 shows the ranking and the averages and standard deviations of the answers. 
Table 1. Descriptive Statistics of the Objectives of Public Relation (PR) Professionals According to Themselves $(N=157)$ and According to Journalists $(N=143)$

\begin{tabular}{|c|c|}
\hline \multicolumn{2}{|c|}{ OBJECTIVES OF PR PROFESSIONALS } \\
\hline According to PR professionals & According to Journalists \\
\hline $\begin{array}{l}\text { (1) PR professionals increase trust between } \\
\text { the organization and the public }(m=2.19 \text {, } \\
s d=0.98)\end{array}$ & $\begin{array}{l}\text { (1) PR professionals support the organization's } \\
\text { financial or political goals }(m=1.50, s d=0.92)\end{array}$ \\
\hline $\begin{array}{l}\text { (2) PR professionals support the organization's } \\
\text { financial or political goals }(m=2.54, s d=1.44)\end{array}$ & $\begin{array}{l}\text { (2) PR professionals take care of the or- } \\
\text { ganization's product or service sales }(m=2.28 \text {, } \\
s d=1.01)\end{array}$ \\
\hline $\begin{array}{l}\text { (3) PR professionals uphold transparency in } \\
\text { the interactions of different facets of society } \\
(m=2.98, s d=1.23)\end{array}$ & $\begin{array}{l}\text { (3) PR professionals increase trust between the } \\
\text { organization and the public }(m=2.81, s d=0.87)\end{array}$ \\
\hline $\begin{array}{l}\text { (4) PR professionals support the functions of a } \\
\text { pluralistic society }(m=3.44, s d=1.48)\end{array}$ & $\begin{array}{l}\text { (4) PR professionals uphold transparency in } \\
\text { the interactions of different facets of society } \\
(m=3.95, s d=1.00)\end{array}$ \\
\hline $\begin{array}{l}\text { (5) PR professionals take care of the or- } \\
\text { ganization's product or service sales ( } m=3.66 \text {, } \\
s d=1.34 \text { ) }\end{array}$ & $\begin{array}{l}\text { (5) PR professionals support the functions of a } \\
\text { pluralistic society }(m=4.33, s d=0.96)\end{array}$ \\
\hline
\end{tabular}

The results indicate statistically highly significant differences between the two groups' perception of PR objectives (ANOVA F-test $\mathrm{p}<0.001$ in all items). In conclusion, PR professionals' main objective to build trust and mediate communication between the society and the organization (Objective 1) is a mixture of orientation towards society (Objective 3 and 4) and orientation towards the organization (Objective 2 and 5). Journalists, on the other hand, emphasize PR professionals' communication orientation towards the organization (Objective 1 and 2) instead of orientation towards society (Objective 4 and 5). Thus, in their opinion PR professionals mainly have their organization's interests in mind.

The second question battery examined strategic perceptions of PR by presenting PR professionals statements about organizational communication strategies and asking which of them they agree and disagree with. Likewise, journalists were asked which strategic statements they assume PR professionals agree and disagree with. The statements were rated from disagree (1) to agree (6). Figure 1 presents arithmetic averages of the perceptions and the valued six statements. For analysis purposes, the statements were divided into two groups: the first two were rated as neutral and the other four as negative statements.

The results indicate statistically highly significant differences between the two groups' perception of PR strategies (ANOVA F-test $p<0.001$ in all items). PR professionals agree most with the first two statements emphasizing organizational transparency (4.66) and acceptance of presenting especially positive aspects of the organization to the public (4.98). PR professionals do not agree with the negatively labelled statements indicating that it is legitimate for organizations to hide negative aspects of their operations (2.36), hide meaningful information (2.28), or disseminate irrelevant information about an organization (2.34). PR professionals disagree most with the statement that it is legitimate for organizations to give incorrect information to the public (1.35). 
Figure 1. Public Relation (PR) Professionals' Strategic Self-images and Perceptions of Journalists (J)

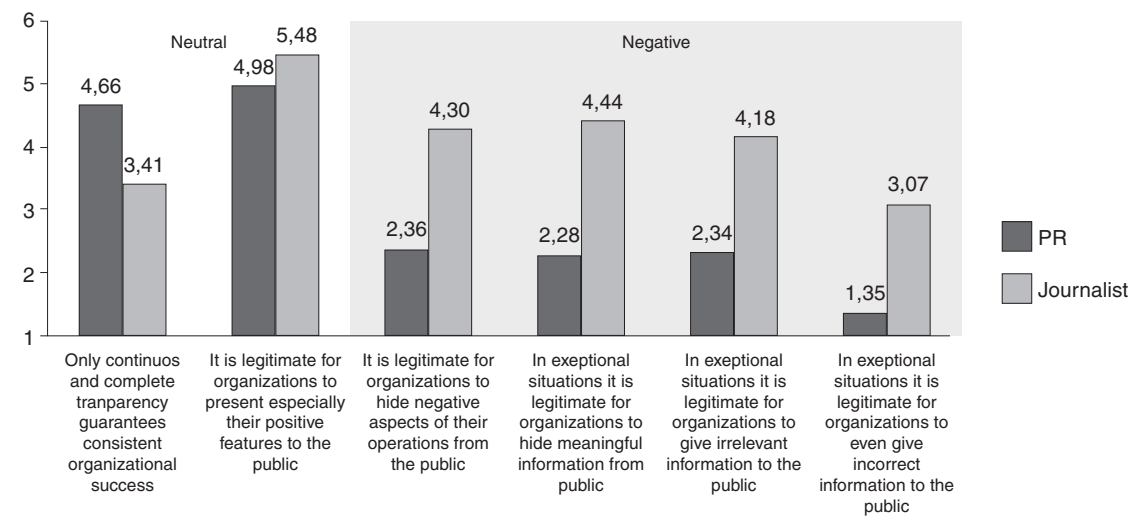

The journalists' assumptions about what PR professionals view as legitimate strategies have both similarities and quite notable differences compared with the views held by PR professionals. Overall, journalists assume that PR professionals accept almost all the strategic statements, the first two neutral and three of the four negative statements. Journalists agree, quite in line with the PR professionals' views, that PR professionals find it acceptable to present mainly positive aspects of the organization to the public (5.48). They, however, disagree somewhat with the statement that PR professionals view transparency as a good strategy (3.41). Differing very clearly from the PR professionals' views, journalists also agree moderately with three of the four negative statements. According to journalists, PR professionals find it legitimate for organizations to hide negative (4.30) and meaningful information (4.44), and to disseminate irrelevant information about an organization (4.18). However, although their average is higher than that of PR professionals, journalists also slightly disagree with the statement that PR professionals find it quite legitimate to give incorrect information to the public (3.07 vs. 1.35).

The third question battery examined general perceptions or images of the PR profession. PR professionals were asked to rate their agreement or disagreement with statements concerning the profession and its communication characteristics, and journalists were asked to do the same. The statements were rated from disagree (1) to agree (6). Figure 2 presents statistical averages of perceptions and the nine statements; the four negative statements are highlighted as in Figure 1.

The results indicate statistically highly significant differences between the two groups' perception (ANOVA F-test $\mathrm{p}<0.001$ in all items). PR professionals disagree with negative statements concerning their communication characteristics, such as that PR professionals are liars (1.23), PR has nothing to do with the truth (1.43), PR professionals have a distorted perspective of reality (1.47), and PR has nothing to do with morals (1.21). They also moderately disagree with the statement that PR does not portray reality but instead ideal images (2.06) and that PR professional are tricky language users (2.58). On the other hand, PR professionals moderately agree with the statements indicating that they cannot always say what they think (4.78), that they have their employer's interests in mind (4.41), and that they cannot always pay attention to public interests (3.89). 
Figure 2. Public Relation (PR) Professionals' and Journalists' (J) Perceptions of the PR Profession and its Communication Characteristics

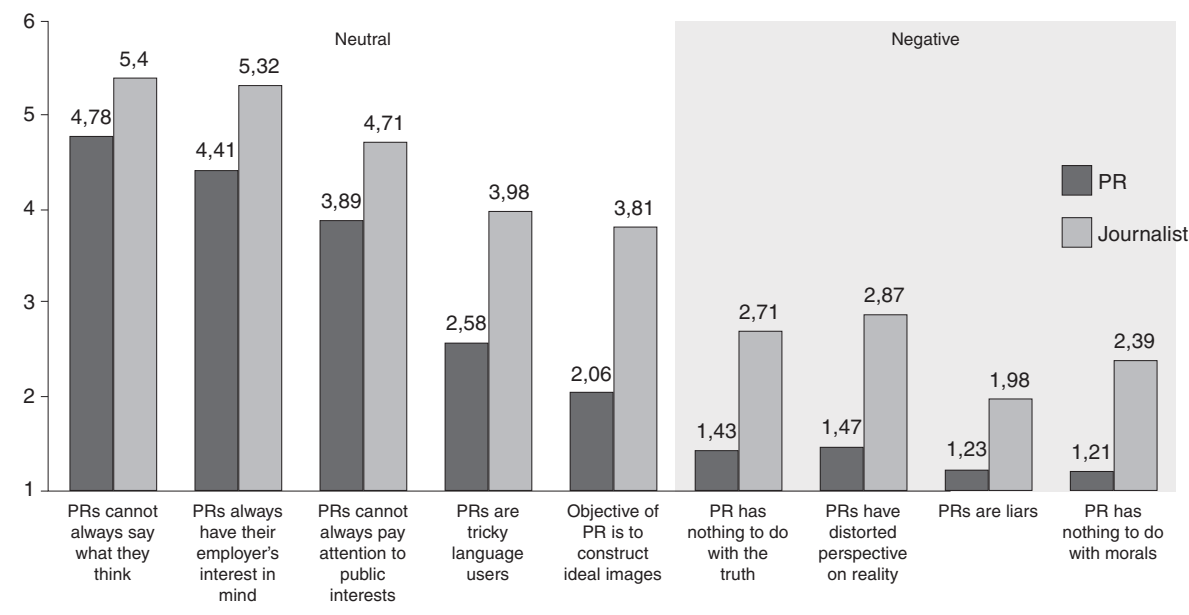

In general, journalists have a more negative view of the PR profession and its communication characteristics. They clearly agree more with the negative statements when compared to PR professionals' own perceptions. Journalists more often feel that PR professionals do not portray reality but instead ideal images (3.81 vs. 2.06$)$ and they more often believe PR professionals are tricky language users (3.98 vs. 2.58). In line with PR professionals, journalists moderately disagree that PR professionals are liars (1.98), that they cannot always say what they think (5.4), that they cannot always pay attention to public interests (4.71), and that they always have their employer's interests in mind (5.32). Neither of the groups believes that PR has nothing to do with truth, and that PR professionals have a distorted perspective on reality or no morals.

\section{Journalists' Functions and Objectives}

\section{- Self-images and PR Professionals'Perceptions}

One extensive question in both PR and journalist questionnaires was designed to examine the professional functions and objectives of journalists. The sixteen statements were categorized under four descriptive categories of objectives (information sharing, criticism and control, opinions and influence, and service). The statements were rated from (1) does not describe at all to (6) describes very well. The results are shown in Table 2, which gives the 16 statements and the average perceptions of journalists and PR professionals.

For most statements, the differences between the two groups' perception of journalists' objectives are statistically significant. In general, journalists believe more often than PR professionals that journalists have information sharing as their objective. In this category, the between-group difference in means for all statements is statistically significant, with journalists usually showing higher ratings. Both groups believe that all statements describe journalists' objectives quite well. Journalists very strongly agree that journalists want to inform the public as neutrally and accurately as possible (5.25), depict reality the way it is (5.20), and explain complicated matters (4.99). PR professionals, 
Table 2. Journalists' (J) Objectives as Perceived by Public Relation (PR) Professionals $(N=157)$ and Journalists $(N=143)$

$N(P R)=157 N(J)=143$

\begin{tabular}{|c|c|c|c|c|c|c|c|c|}
\hline & \multicolumn{2}{|c|}{ Mean } & \multicolumn{2}{|c|}{ Std. Deviation } & \multicolumn{2}{|c|}{ Valid } & \multirow[b]{2}{*}{ F-test } & \multirow[b]{2}{*}{ N-Mean } \\
\hline Journalists want to & PR & $J$ & PR & $J$ & PR & $J$ & & \\
\hline INFORMATION SHARING & 16,80 & 20,08 & 3,22 & 2,61 & 125 & 130 & & 18,44 \\
\hline $\begin{array}{l}\text {...inform the public as } \\
\text { neutrally and accurately as } \\
\text { possible }\end{array}$ & 3,71 & 5,25 & 1,27 & 0,99 & 127 & 130 & *** & 4,48 \\
\hline $\begin{array}{l}\text {...provide information to the } \\
\text { public as fast as possible }\end{array}$ & 5,41 & 4,62 & 0,75 & 1,23 & 128 & 131 & *** & 5,01 \\
\hline ...depict reality the way it is & 3,75 & 5,20 & 1,17 & 1,03 & 126 & 131 & *** & 4,47 \\
\hline $\begin{array}{l}\text {...explain complicated mat- } \\
\text { ters }\end{array}$ & 3,92 & 4,99 & 1,23 & 1,00 & 127 & 131 & *** & 4,46 \\
\hline CRITICISM AND CONTROL & 18,86 & 14,91 & 2,76 & 6,20 & 125 & 143 & & 16,88 \\
\hline ...criticize world maladies & 4,91 & 4,89 & 0,92 & 1,11 & 127 & 131 & - & 4,90 \\
\hline ...monitor political authorities & 4,83 & 4,37 & 0,90 & 1,59 & 126 & 131 & ** & 4,60 \\
\hline $\begin{array}{l}\text {...inform the public about } \\
\text { scandals }\end{array}$ & 4,64 & 2,69 & 1,29 & 1,39 & 127 & 131 & *** & 3,67 \\
\hline ...monitor industrial powers & 4,45 & 4,33 & 1,07 & 1,48 & 127 & 131 & - & 4,39 \\
\hline $\begin{array}{l}\text { OPINIONS AND INFLU- } \\
\text { ENCE }\end{array}$ & 14,58 & 14,11 & 2,94 & 3,31 & 125 & 129 & & 14,34 \\
\hline ...influence daily politics & 4,53 & 3,35 & 1,12 & 1,35 & 128 & 130 & *** & 3,94 \\
\hline $\begin{array}{l}\text {...present their own opinions } \\
\text { and convictions }\end{array}$ & 3,74 & 2,98 & 1,26 & 1,34 & 126 & 130 & $* * *$ & 3,36 \\
\hline $\begin{array}{l}\text {...stand for underprivileged } \\
\text { people }\end{array}$ & 3,54 & 4,28 & 1,22 & 1,30 & 127 & 131 & *** & 3,91 \\
\hline ...transfer positive ideals & 2,78 & 3,48 & 1,11 & 1,31 & 128 & 131 & *** & 3,13 \\
\hline SERVICE & 16,27 & 15,61 & 2,61 & 2,70 & 125 & 131 & & 15,94 \\
\hline $\begin{array}{l}\text {....answer to the needs of } \\
\text { media consumers }\end{array}$ & 4,63 & 5,03 & 1,21 & 1,04 & 126 & 131 & ** & 4,83 \\
\hline $\begin{array}{l}\text {...offer regular people a } \\
\text { chance to express their } \\
\text { opinions }\end{array}$ & 3,57 & 4,16 & 1,12 & 1,36 & 126 & 131 & $* * *$ & 3,87 \\
\hline ...act as advisors & 3,22 & 2,89 & 1,20 & 1,30 & 127 & 131 & * & 3,06 \\
\hline $\begin{array}{l}\text {...provide entertainment for } \\
\text { the public }\end{array}$ & 4,83 & 3,53 & 0,98 & 1,11 & 127 & 131 & $\star \star \star *$ & 4,18 \\
\hline
\end{tabular}

Scale $1=$ does not describe, $6=$ describes very well. $* * *=$ statistical significance $\mathrm{p}<0.001, * *=$ statistical significance $\mathrm{p}<0.01, *=$ statistical significance $\mathrm{p}<0.05,-=$ over $\mathrm{p}>0.05$.

on the other hand, especially believe that journalists want to disseminate information to the public as fast as possible (5.41, cf. 4.62 in journalist ratings).

PR professionals generally believe more often than journalists do that criticism and control are the objectives of journalists. A significant difference in the results is that PR professionals believe that journalists want to inform the public about scandals (4.64), something that journalists do not believe (2.69). There are two statements, with no statistically significant difference between the groups that both groups believe describe the objectives of journalists quite well: Journalists want to criticize world maladies, and 
they want to monitor industrial powers. Both groups also believe that journalists want to monitor political authorities (journalists 4.37, PR professionals 4.83).

In the opinions and influence category, the most marked differences are that PR professionals believe that journalists want to influence daily politics (4.53), present their own opinions and convictions (3.74) and they do not believe that journalists want to transfer positive ideals (2.78). Journalists agree less with the statement about influencing daily politics (3.35); they also indicate a smaller willingness to present their own opinions and convictions (2.98) and their rating (3.48) on transferring positive ideals is higher than PR professionals' (2.78).

In the service category, both groups believe that journalists want to answer to the needs of media consumers (journalists 5.03 and PR professionals 4.63) and that journalists want to offer ordinary people a chance to express their opinions, with journalists showing a somewhat higher rating (journalists 4.16 and PR professionals 3.57). On the other hand, PR professionals seem to believe that journalists want to act as advisors, whereas journalists disagree with the statement (PR professionals 3.22 vs. journalists 2.89). In addition, PR professionals agree more with the statement that journalists want to provide entertainment for the public than journalists do (PR professionals $4.83 \mathrm{vs}$. journalists 3.53 ).

\section{Discussion}

The first question focused on the objectives of PR professionals (Table 1). The results indicate that PR professionals primarily identify bond- and trust-building as their objective. This role is comparable to the communication facilitator (Broom \& Smith 1979) and communication liaison (Dozier 1992) roles. In the context of more recent studies, this objective is closest to the creator role (public relations is about creating a bond) identified by van Ruler (2004). Secondly and thirdly, PR professionals identify themselves with supporting financial and political goals (to some extent related to the conductor role) and with upholding transparency in societal interaction (the traffic manager role). Journalists, on the other hand, perceive that the two most important objectives of PR professionals are to support financial and political goals and take care of product and service sales. This perception relates to the technician role (Dozier 1992). In addition, this role can be related to van Ruler's (2004) town crier role. In brief, the professional self-images of PR professionals and journalists' perceptions of them are rather different. Journalists associate PR objectives more with marketing and financial goals and PR professionals' communication orientation to be towards the organization, whereas PR professionals perceive their own objectives to be more closely related with dissemination and relationship management and their communication to be orientated towards society.

The second PR question (Figure 1) revealed the kind of communication strategies PR professionals view as legitimate and those that journalists assume PR professionals view as legitimate. Both groups agree that the neutral strategies, e.g. emphasizing one's organization's positive features, are legitimate, but journalists also assume that PR professionals consider negative strategies legitimate, such as hiding information and giving irrelevant or even incorrect information. In general, PR professionals emphasize transparency in communication, whereas journalists view PR professionals' communication to be the opposite, even misleading. 
The third question (Figure 2) also provides similar results concerning the image of the PR profession. Both groups agree with the neutral statements related to commonly accepted organizational communication characteristics, such as that PR professionals cannot always say what they want and that they always have their employer's interests in mind. However, the results also indicate that journalists agree much more with the negative statements, such as that PR has nothing to do with morals and that PR professionals have a distorted perspective on reality. Consequently, journalists show notable mistrust towards the PR profession and public relations strategies. These results are in line with the views of many scholars that the PR profession lacks status, image and reputation (e.g., Meintjes \& Niemann-Struweg 2009) and that negative images are the consequence of a lack of professional categorization (van Ruler 2004).

The professional self-image of journalists and PR professionals' perceptions of them were studied with one extensive question battery (Table 2). Both journalists and PR professionals agree with most of the objectives portrayed in the statements. Journalists seem to strongly identify themselves with the information sharing, criticism and service roles. Within these roles, journalists particularly emphasize neutral and accurate informing, political and industrial monitoring and taking the side of the underprivileged. Such roles resemble the professional role typologies of public service and neutral/objective roles (Volek and Jirák 2007) and disseminator role (Wilhoit and Weaver 1996), in addition to the advocate/adversarial role (e.g., Volek and Jirák 2007). Generally, journalists claim to abstain from voicing their own opinions and convictions, acting as advisors, and informing the public about scandals. PR professionals, on the other hand, view the aforementioned as journalists' objectives. Overall, journalists in Finland are apparently drawn to the "information model - the 'provide the facts, let the public decide' school of journalism thinking” (Macnamara 2007: 6). In conclusion, journalists view their objectives as more 'noble' and feel they take almost an activist role in society, whereas PR professionals view the objectives of journalists as more 'entertaining' and as involving more self-disclosure and self-emphasis. PR professionals, thus, may emphasize the new career/pragmatic objective introduced by Volek and Jirák (2007), according to which journalists' objectives are guided by personal work advancement and success instead of by idealistic goals or social well-being.

In conclusion, the answer to the three research questions is summarized in Table 3. The questions are: (1) How do PR professionals and journalists perceive their own professions and objectives? (2) What kind of perceptions do PR professionals and journalists have of each other's professions and objectives? (3) What kinds of differences are there between professional self-images and the other group's perception? The first two columns present professional self-images and the other group's perception based on the research findings of the present study in the form of new role descriptions, which are written in capital letters. The corresponding role typologies found in earlier studies are presented after each new role description. The third column presents a summary of the differences between the perceptions. 
Table 3. Professional Self-images and Perceptions by Journalists and Public Relation Professionals of the Other Group's Profession

\begin{tabular}{|c|c|c|c|}
\hline & $\begin{array}{l}\text { (1) Professional self- } \\
\text { image }\end{array}$ & $\begin{array}{l}\text { (2) Role perception accord- } \\
\text { ing to the other group }\end{array}$ & $\begin{array}{l}\text { (3) Differences in } \\
\text { perceptions }\end{array}$ \\
\hline \multirow[t]{2}{*}{ Journalists } & $\begin{array}{l}\text { NEUTRAL INFORMERS } \\
\text { public service and neutral/ } \\
\text { objective } \\
\text { (Volek and Jirák 2007) }\end{array}$ & \multirow{2}{*}{$\begin{array}{l}\text { ENTERTAINERS WITH SELF- } \\
\text { EMPHASIS/DISCLOSURE } \\
\text { OBJECTIVES } \\
\text { career/pragmatic } \\
\text { (Volek and Jirák 2007) }\end{array}$} & \multirow{2}{*}{$\begin{array}{l}\text { Journalists identify them- } \\
\text { selves as informers and } \\
\text { public servants, whereas } \\
\text { PRs identify journalists as } \\
\text { oriented towards career } \\
\text { success, personal goal } \\
\text { achievements and scan- } \\
\text { dalous reporting }\end{array}$} \\
\hline & $\begin{array}{l}\text { PROPONENTS OF THE } \\
\text { WEAK AND SOCIETAL } \\
\text { MONITORS } \\
\text { advocate/adversarial } \\
\text { (Volek and Jirák 2007) }\end{array}$ & & \\
\hline \multirow[t]{2}{*}{$\begin{array}{l}\text { PR profes- } \\
\text { sionals }\end{array}$} & $\begin{array}{l}\text { BOND AND TRUST BUILD- } \\
\text { ERS } \\
\text { creator (van Ruler 2004) }\end{array}$ & $\begin{array}{l}\text { MARKETERS WITH FINAN- } \\
\text { CIAL AND POLITICAL OBJEC- } \\
\text { TIVES } \\
\text { technician (Dozier 1992) }\end{array}$ & \multirow{2}{*}{$\begin{array}{l}\text { PRs identify themselves } \\
\text { as bond, trust, commu- } \\
\text { nication and transpar- } \\
\text { ency enablers whereas } \\
\text { journalists show mistrust } \\
\text { towards PR objectives } \\
\text { and strategies and } \\
\text { identify PR orientations } \\
\text { towards marketing and } \\
\text { corporate gain }\end{array}$} \\
\hline & $\begin{array}{l}\text { COMMUNICATION AND } \\
\text { TRANSPARENCY ENA- } \\
\text { BLERS } \\
\text { communication facilitator } \\
\text { (Broom \& Smith 1979) com- } \\
\text { munication liaison (Dozier } \\
\text { 1992) traffic manager (van } \\
\text { Ruler 2004) }\end{array}$ & $\begin{array}{l}\text { PRESENTERS OF } \\
\text { THE ORGANIZATION'S } \\
\text { LEADERS' VOICE } \\
\text { town crier (van Ruler 2004) }\end{array}$ & \\
\hline
\end{tabular}

\section{Conclusions}

Most of the previous research literature describes the relationship of PR professionals and journalists as highly negative and opposing (e.g., Schriner 2008 and Jempson 2005). New studies in the area of PR and journalist professional relations have taken a more positive view towards the formation of their cooperative relationships (e.g., Waters, Tindall \& Morton 2010). The present study shows that the two professional groups' perceptions of each other are rather different, even negative, and that the relationship still appears to be conflicting in Finland.

The perception differences of PR professionals and journalists in Finland can stem from the various underlying reasons described in the literature review presented here, including negative experiences leading to mistrust, perceptions of one's own occupation's superiority, differing objectives or lack of knowledge. As a young profession in Finland when compared to journalism, PR may still today lack professional definition, clarity in its objectives, and thus also respect among journalists and society at large. In addition, as stated in the methods section, PR professionals have more experience in journalism than journalists have experience in PR work, which may to some extent explain the similarities in the two groups' perception of journalist objectives and roles as well as some of the negative images held by journalists concerning PR professionals and their objectives. Regardless, nearly half of both groups state their willingness to work in the other profession in the future, a finding that does not fit well with the present 
results on negative images. Further interview research may help to clarify these results and their implications in more detail.

The present descriptive study brings about interesting findings, but it also has some limitations. First, the study was based on a readymade questionnaire and only part of the ProfCom question batteries was used to address the present research questions. Second, the questionnaire was translated from its original German to Finnish and the answers were translated from Finnish to English, which may have an impact on the results. Nevertheless, there was a large number respondents, both PR professionals and journalists, and they were representative of their respective groups, which increases the reliability of the study.

At present, the communication field is characterized by developments that influence the roles and relationships of PR professionals and journalists. For instance, news recycling and the growing influence of direct PR material usage in news production are issues that are transforming the cooperation of communication professionals. Furthermore, the Internet and social media have had enormous effects on the processes of the entire communication atmosphere in society. To complement the results of the present study, it would seem to be insightful and important to study how the novel online news and communication ecosystem has changed the roles and relationships of communication professionals.

\section{Note}

1. The present article is based on a questionnaire developed in the Professional Communicators in Europe (ProfCom) project. The authors wish to thank the Vienna research group, especially Professor Roland Burkart. Special thanks also go to Professor Emeritus Jaakko Lehtonen and Pauliina Palttala, both of the University of Jyväskylä, for managing the early stages of the research and translating the questionnaire into Finnish.

\section{References}

Berent, M.K., Boninger, D.S. and Krosnick, J. A. (1995) 'Origins of Attitude Importance: Self-Interest, Social Identification, and Value Relevance', Journal of Personality and Social Psychology 68(1): 61-80.

Bowen, S.A. (2009) 'All glamour, no substance? How public relations majors and potential majors in an exemplar program view the industry and function', Public Relations Review 35: 402-410.

Broom, G.M. and Smith, G.D. (1979) 'Testing the Practitioner's Impact on Clients', Public Relations Review 5(3): 47-59.

Charron, J. (1989) 'Relations Between Journalists and Public Relations Practitioners: Cooperation, Conflict and Negotiation', Canadian Journal of Communications 14(2): 41-54.

Collard, J. (2004) 'Learners, Initiators, Servants: The Self-Images of Victorian Principals in the 1990s', The Australian Educational Researcher 31(1): 37-56.

Culbertson, H. (1983) 'Three perspectives of American Journalism', Journalism Monographs, June 1983.

Dozier, D.M. (1992) 'The Organizational Roles of Communications and Public Relations Practitioners', in Gruning, J. E. (ed.) Excellence in public relations and communication management. Hillsdale NJ: Lawrence Erlbaum.

Dutton, W.H. (2009) 'The Fifth Estate Emerging through the Network of Networks', Prometheus 27(1): 1-15.

Fombrun, C.J. and van Riel, C.B.M. (2004) Fame \& Fortune. How Successful Companies Build Winning Reputations. New Jersey: Pearson Education, Inc.

Graeff, T.R. (1996) 'Using Promotional Messages to Manage the Effects of Brand and Self-Image on Brand Evaluations', Journals of Consumer Marketing 13(3): 4-18.

Hallin, D.C. and Mancini, P. (2004) Comparing media systems: Three models of media and politics. Cambridge: Cambridge University Press.

Heath, A.P. and Scott, D. (1998) 'The Self-Concept and Image Congruence Hypothesis: An Empirical Evaluation in the Motor Vehicle Market', European Journal of Marketing 32(11/12): 1110-1123. 
Jempson, M. (2005) 'Spinners or Sinners? PR, Journalists and Public Trust', Journal of Communication Management 9(3): 267-276.

Johnston, W.C., Slawiski, E. and Bowman, W. (1976) The News People: A Sociological Portrait of American Journalists and Their Work. Urbana: University of Illinois Press.

Jyrkiäinen (2012) 'Sanomalehdistö' (Newspaper industry), in Nordenstreng, K. and Wiio, O.A. (eds.) Suomen mediamaisema (Finnish media scene). Tampere: Vastapaino.

Karppinen, K., Nieminen, H. and Markkanen, A-L. (2011) 'Finland: Higher Professional Ethos in a Small Concentrated Media Market' in Trappel, J., Nieminen, H. and Nord, L. (eds.) The Media for Democracy Monitor. A Cross National Study of Leading News Media. University of Gothenburg: Nordicom.

Kirpal, S. (2004) 'Researching Working Identities in a European Context', Career Development International 9(3): 199-221.

Kotler, P. (1997) Marketing Management: Analysis, Planning, Implementing and Control. Upper Saddle River, N.J.: Prentice-Hall.

Larsson, L. (2009) 'PR and the Media. A collaborative Relationship?', Nordicom Review 30(1): 131-147.

Lehtonen, J. (2002) Julkisuuden riskit (Risks of publicity). Helsinki: Ykköset-Offiset Oy.

Macnamara, J. (2007) 'The Fork in the Road and Communication Theory and Practice'. Institute for Public Relations. Online: http://www.instituteforpr.org.

Meintjes, C. and Niemann-Struweg, I. (2009) 'The Role of a Professional Body in Professionalisation: The South African public relations case', PRism 6(2): 1-14. Online: http://praxis.massey.ac.nz/prism_online journ.html.

Nieminen, H. and Nordenstreng, K. (2012) 'Sääntely ja viestintäpolitiikka' (Regulation and communication policy), in Nordenstreng, K. and Wiio, O. A. (eds.) Suomen mediamaisema (Finnish media scene). Tampere: Vastapaino.

Ohman, K. (1992) Self-image, interpersonal interactions and psychopathology. Umeå: Printing Office of Umeå University.

Official Statistics of Finland (2011a) Mass media statistics [e-publication]. Personnel of mass communication enterprises 2001-2011. Online: http://tilastokeskus.fi/til/jvie/tau_en.html (read 15.3.2013)

Official Statistics of Finland (2011b) Mass media statistics [e-publication]. Television passed the one billion mark - preliminary data on the mass media market in 2011. Online: http://tilastokeskus.fi/til/jvie/2011/ jvie_2011_2012-05-24_tie_001_en.html (read 15.3.2013)

ProfCom (2011) Professional Communicators in Europe. A Comparative Study on Self-Concepts of Journalists and Public Relations-Managers. University of Vienna. Online: http://profcom.univie.ac.at/en/ (read 12.1.2011)

Robson, J. (1998) 'A Profession in Crisis: Status, Culture and Identity in the Further Education College', Journal of Vocational Education and Training 5(4): 585-607.

Rogers, T.B., Kuiper, N.A., and Kirker, W.S. (1977) 'Self-Reference and the Encoding of Personal Information', Journal of Personality and Social Psychology 35: 677-688.

Ryan, M. and Martinson, D. L. (1988) 'Journalists and Public Relations Practitioners: Why the Antagonism?', Journalism Quarterly 65(1): 131-140.

Salter, L. (2005) 'The communicative structures of journalism and public relations', SAGE Publications 6(1): 90-106. Online: http://jou.sagepub.com/cgi/content/abstract/6/1/90

Schriner, M. (2008) 'The Public Role Model in Public Relations: An Integrated Approach to Understanding Personal Influence in the Public Arena'. Paper presented at Euprera 2008. Online: http://www.instituteforpr.com/files/uploads/Maureen_Schriner.pdf

Siebens, K. et al. (2006) 'The Professional Self-Images of Nurses in Belgian hospitals: A Cross-Sectional Questionnaire Survey', International Journal of Nursing Studies 43: 71-82.

Shin, J.H. and Cameron, G.T. (2004) 'Conflict measurements: analysis of simultaneous inclusion in roles, values, independence, attitudes, and dyadic adjustment', Public Relations Review 30: 401-410.

Simmons, P. and Walsh, B. (2010) 'Disliking public relations: Democratic ideals and the habits of ethical communicators', International Journal of Communication Ethics 7(4): 13-19.

Trappel, J., Nieminen, H. and Nord, L. (2011) 'Editorial', in Trappel, J., Nieminen, H and Nord, L. (eds.) The Media for Democracy Monitor. A Cross National Study of Leading News Media. University of Gothenburg: Nordicom.

Van Ruler, B. (2004) 'The Communication Grid: An Introduction of a Model of Four Communication Strategies', Public Relations Review 30: 123-143.

Viestinnän ammattilaiset -tutkimus (2011) (Communication professional survey 2011). Online: http://procomfi bin.directo.fi/@Bin/9772eb688d9ea099b1aaac45ba8d61c7/1363168842/application/pdf/659768/ Viestinn\%C3\%A4n\%20ammattilaiset\%202011\%20loppuraportti.pdf (read 10.2.2013)

Volek, J. and Jirák, J. (2007) 'Professional Self-Image of the Czech Journalists: Selected Attributes', Media studies IV 2007: 358-374. 
Von Hertzen, P., Melgin, E. and Åberg, L. (2012) Vuosisata suhdetoimintaa - Yhteisöviestinnän historia Suomessa (A Century of PR in Finland). Kustannusosakeyhtiö Otava.

Waters, R.D., Tindall, N.T.J. and Morton, T. S. (2010) 'Media Catching and the Journalist - Public Relations Practitioner Relationship: How Social Media are Changing the Practice of Media Relations', Journal of Public Relations Research 22(3): 241-264.

Webb, J.R. (2000) 'An inquiry into the Professional Self Image of Real Estate Agents', Journal of Real Estate Research (JRER) 20(1/2): 153-177.

Wilhoit, G.C. and Weaver, D. (1996) The American Journalists in the 1990s: U.S. News People at the End of an Era. New Jersey: Lawrence Erlbaum.

World Democracy Audit. (2012) Democracy table December 2012. Online: http://www.worldaudit.org/ democracy.htm (read 1.4.2013

NIINA NISKALA, Ph.D. Candidate, Researcher, Department of Communication, University of Jyväskylä, niina.niskala@jyu.fi

PERTTI HURME, Ph.D., Senior Lecturer Emeritus, Department of Communication, University of Jyväskylä, pertti.hurme@jyu.fi 